\title{
A tribute to Fink (1956): On the correlation of terraces and loesses in Austria
}

Tobias Sprafke

Kompetenzzentrum Boden (Center of Competence for Soils), BFH-HAFL, Länggasse 85, 3052 Zollikofen, Switzerland

Correspondence: Tobias Sprafke (tobias.sprafke@bfh.ch)

Relevant dates: $\quad$ Received: 8 August 2021 - Accepted: 5 November 2021 - Published: 17 December 2021

How to cite: $\quad$ Sprafke, T.: A tribute to Fink (1956): On the correlation of terraces and loesses in Austria, E\&G Quaternary Sci. J., 70, 221-224, https://doi.org/10.5194/egqsj-70-221-2021, 2021.

Special issue statement. This article is part of a special issue published on the occasion of the 70th anniversary of $E \& G$ Quaternary Science Journal (EGQSJ). The special issue celebrates the journal's notable contribution to Quaternary research by revisiting selected milestone articles published in the long history of EGQSJ. The German Quaternary Association (DEUQUA) presents translations of the originals and critical appraisals of their impact in tandem anniversary issues of DEUQUASP and EGQSJ, respectively.

Original article: https://doi.org/10.3285/eg.07.1.07

Translation: https://doi.org/10.5194/deuquasp-341-2021

\section{Historical context}

Julius Fink did not discover a new continent, he did not develop a new research technique, he made no important archeological find, and he did not describe an unknown mineral or species. Fink created a holistic framework linking geology, physical geography, and soil science close to his hometown of Vienna. He collected detailed field evidence from numerous loam pits and other outcrops, thereby managing to solve a number of complications in a region that seemed well-studied but, looking in detail, was full of contradictory evidence. Fink had large shoes to fill when presenting his results on a five-day excursion following the DEUQUA meeting in Laufen near Salzburg (Austria) in 1955. His follow-up paper treated here established key concepts of loess and ter- race stratigraphy and their geographical differences, largely valid today (Sprafke, 2016; Terhorst et al., 2015).

A major footprint before Fink was the seminal work of Penck and Brückner (1909) which established that at least four major glaciations occurred in the eastern Alps. These were (from oldest to latest): Günz, Mindel, Riss (i.e., penultimate glacial), and Würm (i.e., last glacial). Key pieces of evidence were glacial moraines linked to fluvioglacial terraces in the Alpine foreland, whereas the widespread loess cover played a minor role in this concept. As terraces were linked to moraines and thus to glacial periods, their loamy covers (absent on the lowermost, last glacial terrace) were attributed to interglacials. This misconception was soon invalidated: loess represents glacial periods, and intercalated paleosols represent interglacials or interstadials (Soergel, 1919).

Many footprints were left by generations of archeologists that made important discoveries in the Austrian loess landscapes, especially in the Krems-Wachau region. The Venus of Willendorf discovered in 1908 remains until now a symbol for the European Paleolithic. The nearby remarkable loess outcrops at Krems, Göttweig, and Paudorf, with their welldeveloped paleosols, played an important role in fierce discussions between Quaternary geologists and archeologists on how to subdivide the ice age and related Paleolithic cultures.

Probably the most immediate footprint for Fink was left by Götzinger (1936). On a field trip through the Alpine forelands in the context of the INQUA conference in Vienna, Götzinger internationally established the Krems, Göttweig, and Paudorf loess-paleosol sequences (LPSs) as type lo- 
calities of Quaternary stratigraphy. The Krems, Göttweig, and Paudorf paleosols were thought to represent the "long" Mindel-Riss interglacial $(\sim$ marine oxygen isotope stages (MISs) 11/9-7), the "last" Riss-Würm interglacial ( MIS 5 e), and the single marked Würm interstadial ( $\sim$ MIS 3$)$, respectively.

\section{Loess and terrace stratigraphy}

Today we know from continuous marine and ice core oxygen isotope records that over 50 glacial-interglacial cycles and numerous suborbital climatic oscillations occurred during the Quaternary. At the same time each landscape and archive has its distinct response to these paleoclimatic changes, hampering unified stratigraphies, especially when absolute dating techniques are not available. Until the 1950s, Quaternary research was essentially a field science, and the small national and international communities did field trips to personally observe and discuss stratigraphic evidence brought forward by colleagues.

Götzinger (1936) realized the potential of LPS in the Krems region to refine Quaternary stratigraphy and presented impressive outcrops at Paudorf, Göttweig, and Krems as type localities. Fink expressed his strong skepticism with this choice 20 years later as these localities had no clear connection to stratigraphically robust terraces. It was in the region between Salzburg and Linz (NW Austria), studied in detail by Penck and Brückner (1909), where Fink realized that the connection of fluvioglacial terraces (previously linked to glacial moraines) and loess was too obvious to be ignored: the lowermost terrace (in German: Niederterrasse) represents the last glacial period and is therefore free of loess, and the next higher terrace (in German: Hochterrasse) represents the penultimate glacial, contains the last interglacial paleosol, and is superimposed by a last glacial LPS. A thick LPS on higher terrace levels (different Deckenschotter units) can record several glacial-interglacial cycles.

In NW Austria, close to the former piedmont glaciers, Fink managed to convincingly complement the Penck and Brückner (1909) scheme with loess stratigraphy. The latter provided details of glacial paleoenvironments not visible from moraines and terraces (Terhorst et al., 2015). In NE Austria ( $\mathrm{N}$ of Vienna), far from the piedmont paleoglaciers, Fink identified an overall similar stratigraphic pattern compared to the one of NW Austria, however with markedly different expressions of paleosols and sediments. He suggested a regional terrace stratigraphy for NE Austria based on the insights from geomorphology and loess stratigraphy, although he was less confident with this connection due to the influence of neotectonics in the Vienna Basin. The Krems region with its complex pattern of terraces and impressive LPS of highly variable ages was largely avoided in the stratigraphic schemes of Fink.
Despite regional differences of the LPSs, Fink created a robust stratigraphic framework for the Austrian loess landscapes in connection to terraces and based on this to glacial moraines. While he was skeptical about Götzinger's choice of type localities in the Krems region, he agreed to his notion that the last glacial period had only one clear interstadial. While Götzinger (1936) had used the Paudorf soil, Fink selected the Stillfried B paleosol of NE Austria and a marked tundra gley in NW Austria as stratigraphic markers for this single interstadial of the last glacial. This twofold last glacial period contrasted to the widely shared view of a tripartite subdivision of the last glacial period (Soergel, 1919; Woldstedt, 1956).

\section{Paleoenvironments}

From today's perspective, the pedostratigraphic advances by Fink seem of little relevance as we have modern techniques to date organic matter up to $50 \mathrm{ka}$ and far older phases of sedimentation, using, e.g., optically stimulated luminescence dating (Thiel et al., 2011). With these tools we are able to detect local changes in sedimentation rates and pathways of pedogenesis, which we can link to regional paleoenvironments and even paleoclimatic evolution (Sprafke, 2016). Already Fink realized during his stratigraphic work that there are marked differences in LPS between NW Austria and NE Austria which correspond to different present-day climatic and ecological conditions. His German colleague, Brunnacker (1956), followed the same approach for Bavaria, differentiating loess facies regions according to (paleo-)climatic differences in N Bavaria (Franconia) and S Bavaria. In Austria the gradient between the "humid" and the "dry" loess landscape is stronger as the Bohemian Massif between these areas acts as a topographic barrier for moisture brought by the westerlies.

While Fink is internationally well-known for loess research, it should be highlighted that he contributed to numerous soil maps and considerably advanced soil geography in Austria and beyond. In his concept of loess landscapes, he virtuously linked geology, physical geography, and soil science. The humid loess landscape in NW Austria receives $600-800 \mathrm{~mm}$ mean annual precipitation, and present-day soils from loess are Luvisols that typically develop in deciduous forest ecosystems. To the east of the Bohemian Massif precipitation is only around $500 \mathrm{~mm}$ per year, and present-day soils largely correspond to Chernozems that form potentially in steppe ecosystems. Different morphologies of LPS E and W of the Bohemian Massif can be explained by overall similar paleoclimatic gradients (Sprafke, 2016).

Fink realized that similar to the present-day soil, interglacial paleosols of the humid loess landscape (developed in loess or terrace sediments) correspond to well-developed Luvisols, partly with strong redoximorphic features. The inter- 
glacial Luvisol remnants and polygenetic pedosediments on top are termed "Linzer Komplex". Superimposed are brown, decalcified loess sediments, at least one major tundra gley and calcareous loess. Unlike the present-day Chernozems, the last interglacial paleosol in the dry loess landscape corresponds to a Cambisol, thus indicating advanced weathering compared to the present-day soil but still more weakly developed in comparison to the last interglacial soil of the humid loess landscape. At the type locality Stillfried A, the "Stillfrieder Komplex", correlative to the "Linzer Komplex", consists of the last interglacial Cambisol and three Chernozems separated by loess layers. Stillfried B is a topographically higher profile with a weak paleosol, which is correlated to the major Würm interstadial (cf. Terhorst et al., 2015).

Although the localities of the Krems-Wachau region (e.g., Paudorf, Göttweig, Krems, Willendorf) were widely known to archeologists and Quaternary researchers, Fink avoids detailed discussions on loess profiles of what he calls a "transition region"; this area is defined as the Wachau Valley and the E margin of the Bohemian Massif. Fink gives an overview of the main stratigraphic features in this region and suggested that the local paleosols are comparable to those of the dry loess landscape, but early last glacial reworking is comparable to the humid loess landscape. Fink admits that the terrace stratigraphy is complicated in the transition region and that it is not possible to provide reliable links to the terrace scheme in NW Austria, close to the paleoglaciers, where we are in Fink's words "forced to accept" Penck's nomenclature. Fink regrets the lack of studies linking the NW Austrian terrace stratigraphies to those of the Krems region and the Vienna Basin - a problem that persists until today (Sprafke, 2016).

An important aspect of Fink's work is the correlations of his loess stratigraphies to those of other regions in the loess belt between Belgium and (former) Yugoslavia. Note that Fink expands his text to where he is able to report from his own field observations. It appears he trusts his own eyes more than what is said or even written in publications given his tendency to reinterpret findings from colleagues. This focus on one's own field observations appears unusual from a modern perspective, in which findings require independent support by quantitative data. Summarizing his discussion on profiles from other regions, Fink was able to connect his own findings to those of other loess landscapes as there are in general comparable patterns in loess-paleosol successions - a remarkable achievement without absolute chronology. Possibly the unified stratigraphy from (paleo-)climatically distinct regions allowed him to understand profiles in the oceanic and continental parts across the European loess belt.

\section{Further development}

In 1956, Fink realized that field evidence was insufficient to discuss the transition region in detail. Radiocarbon ages from so-called Paudorf soils and Göttweig soils of different arche- ological sites became available five years later, and Fink accepted an age of ca. $30 \mathrm{ka}$ for the Paudorf interstadial, which he correlated to Stillfried B. Following Götzinger (1936), Fink (1961) proposed that the Göttweig soil correlates to the last interglacial and thus the lower parts of the "Stillfrieder Komplex" and "Linzer Komplex". At this time, the Quaternary research community agreed to abandon the tripartite subdivision of last glacial period, and Fink finally succeeded in integrating the transitional region with its famous loess sections into Austrian loess stratigraphy.

Also in 1961, at the loess symposium of the INQUA conference in Warsaw (Poland), Fink and colleagues established the INQUA subcommission of loess stratigraphy. The notion that the first well-developed brown loess paleosol (usually a truncated Luvisol) below the surface represented the last interglacial found wide acceptance as a "stratigraphic rule". On the first annual subcommission field trips in Central Europe, this rule worked well, but in the late 1960s after field trips to Hungary and Serbia, there were increasing doubts that the stratigraphic rule is universally applicable and that the type localities of the transition region in Austria were adequate. The loess subcommission reached full commission status during the INQUA congress in Paris 1969, but at the same time Fink had to announce unfortunate news. According to malacological and paleomagnetic results obtained by Czech colleagues from Krems, Göttweig, and Paudorf paleosols (e.g., Vojen Ložek, Jiří Kukla), the respective units were considerably older, i.e., Early Pleistocene, Middle Pleistocene, Last Interglacial, respectively (see Sprafke, 2016).

During the 1970s until his death, Fink worked with Jiri (George) Kukla on Pleistocene land-sea correlations, providing results from the Old Pleistocene loess records of Krems and Stranzendorf. With the emerging marine stratigraphy, loess lost its key role to subdivide the Quaternary - at least for European LPS because complete loess sections at the Chinese loess plateau attracted an increasing number of researchers. The classical tetraglacial scheme of Penck and Brückner (1909) remains useful in the forelands of the eastern Alps, but internationally it is only of historical relevance.

In the 1990s the establishment of luminescence dating led to some revival of loess research in Central Europe and some key sites like those in Lower Austria finally had absolute age information (Zöller et al., 1994). In the last decade, the growing interest in regional paleoclimate records and the paleoenvironmental contexts of Paleolithic humans have resulted in intensified research on loess (Lomax et al., 2014; Sprafke, 2016; Terhorst et al., 2015). It should not be forgotten that a key observation of Fink was the significance of LPS to understand past climate and landscape evolution, which appears largely blurred by the stratigraphic confusion during the following decades. The concept of loess landscapes highlights the imprint of (paleo-)climate on paleosol properties, which can be used to reconstruct regional effects of past climatic changes (Sprafke, 2016; Terhorst et al., 2015). 
Nowadays, loam pits are rare, and field observations are often limited to sampling time. With the emergence of big data geoscience, the paper of Fink may to many just appear as historical science. However, key concepts developed in these times are still valid, and key challenges remain until today. Some details need revision; for example, the last glacial tundra gley of the humid loess landscape is most likely Upper Würm, as the Middle Würm is represented by brown soils, including the equivalent to the Lohne soil and Stillfried B (Terhorst et al., 2015). Despite modern geochronology techniques (e.g., advanced luminescence dating protocols, cosmogenic nuclide dating, and refined paleomagnetics) and advances in quantitative modeling, there remain many more open questions on loess and terrace stratigraphy in the Alpine foreland. Certainly, detailed and careful field observations complemented by appropriate modern analytical techniques and based on a holistic understanding of the complex interplay of natural processes are of great importance to resolve these questions and pedosedimentary and landscape evolution in general - a lesson we also learn from Fink.

Acknowledgements. Many thanks to Birgit Terhorst and Robert Peticzka for introducing me to Austrian loess, the fascinating world of Julius Fink. Also thanks to Bernhard Salcher for helpful review comments to improve this paper and many thanks to Christine Thiel for the editorial handling and important remarks during the preparation of this paper.

Financial support. The article processing charge was funded by the Quaternary scientific community, as represented by the host institution of EGQSJ, the German Quaternary Association (DEUQUA).

Review statement. This paper was edited by Christine Thiel and reviewed by Bernhard Salcher.

\section{References}

Brunnacker, K.: Regionale Bodendifferenzierungen während der Würmeiszeit, E\&G Quaternary Sci. J., 7, 43-48, https://doi.org/10.3285/eg.07.1.06, 1956.

Fink, J.: Zur Korrelation der Terrassen und Lösse in Österreich, E\&G Quaternary Sci. J., 7, 49-77, https://doi.org/10.3285/eg.07.1.07, 1956.

Fink, J.: Die Gliederung des Jungpleistozäns in Oesterreich, Mitteilungen der Geologischen Gesellschaft in Wien, 54, 1-25, 1961.

Götzinger, G.: Das Lößgebiet um Göttweig und Krems an der Donau, in: Führer für die Quartär-Exkursionen in Österreich, edited by: Götzinger, G., Geologische Bundesanstalt, Wien, pp. 1-11, 1936.

Lomax, J., Fuchs, M., Preusser, F., and Fiebig, M.: Luminescence based loess chronostratigraphy of the Upper Palaeolithic site Krems-Wachtberg, Austria, Quatern. Int., 351, 88-97, 2014.

Penck, A. and Brückner, E.: Die Eiszeiten in den nördlichen Ostalpen (= Die Alpen im Eiszeitalter Band 1), Tauchnitz, Leipzig, 393 pp., 1909.

Soergel, W.: Löße, Eiszeiten und paläolithische Kulturen. Eine Gliederung und Altersbestimmung der Lösse, Fischer, Jena, 177 pp., 1919.

Sprafke, T.: Löss in Niederösterreich - Archiv quartärer Klima- und Landschaftsveränderungen, Dissertation, Würzburg University Press, Würzburg, 272 pp., available at: https://opus.bibliothek.uni-wuerzburg.de/files/12778/ 978-3-95826-039-9_Sprafke_Tobias_OPUS_12778.pdf (last access: 26 November 2021), 2016.

Terhorst, B., Sedov, S., Sprafke, T., Peticzka, R., Meyer-Heintze, S., Kühn, P., and Solleiro Rebolledo, E.: Austrian MIS 3/2 loesspalaeosol records - Key sites along a west-east transect, Palaeogeogr. Palaeocl., 418, 43-56, 2015.

Thiel, C., Buylaert, J.-P., Murray, A. S., Terhorst, B., Tsukamoto, S., Frechen, M., and Sprafke, T.: Investigating the chronostratigraphy of prominent palaeosols in Lower Austria using post-IR IRSL dating, E\&G Quaternary Sci. J., 60, 11, https://doi.org/10.3285/eg.60.1.10, 2011.

Woldstedt, P.: Über die Gliederung der Würm-Eiszeit und die Stellung der Lösse in ihr, E\&G Quaternary Sci. J., 7, 78-86, https://doi.org/10.3285/eg.07.1.08, 1956.

Zöller, L., Oches, E. A., and McCoy, W. D.: Towards a revised chronostratigraphy of loess in Austria with respect to key sections in the Czech Republic and in Hungary, Quaternary Sci. Rev., 13, 465-472, 1994. 